Article

\title{
Solidarity Cities and Cosmopolitanism from Below: Barcelona as a Refugee City
}

\author{
Óscar García Agustín and Martin Bak Jørgensen * \\ Department of Culture and Global Studies, Aalborg University, 9220 Aalborg, Denmark; E-Mails: oscar@cgs.aau.dk (O.G.A.), \\ martinjo@cgs.aau.dk (M.B.J.) \\ * Corresponding author
}

Submitted: 12 March 2019 | Accepted: 24 May 2019 | Published: 27 June 2019

\begin{abstract}
The so-called 'refugee crisis' provoked a wave of solidarity movements across Europe. These movements contrasted with attitudes of rejection against refugees from almost all EU member states and a lack of coordinated and satisfactory response from the EU as an institution. The growth of the solidarity movement entails backlash of nationalized identities, while the resistance of the member states to accept refugees represents the failure of the cosmopolitan view attached to the EU. In the article, we argue that the European solidarity movement shapes a new kind of cosmopolitanism: cosmopolitanism from below, which fosters an inclusionary universalism, which is both critical and conflictual. The urban scale thus becomes the place to locally articulate inclusive communities where solidarity bonds and coexistence prevail before national borders and cosmopolitan imaginaries about welcoming, human rights, and the universal political community are enhanced. We use the case of Barcelona to provide a concrete example of intersections between civil society and a municipal government. We relate this discussion to ongoing debates about 'sanctuary cities' and solidarity cities and discuss how urban solidarities can have a transformative role at the city level. Furthermore, we discuss how practices on the scale of the city are up-scaled and used to forge trans-local solidarities and city networks.
\end{abstract}

\section{Keywords}

Barcelona; cosmopolitanism; municipalism; refugee crisis; solidarity

\section{Issue}

This editorial is part of the issue "The European Refugee Controversy: Civil Solidarity, Cultural Imaginaries and Political Change", edited by Gert Verschraegen (University of Antwerp, Belgium) and Robin Vandevoordt (University of Oxford, UK/University of Antwerp, Belgium).

(C) 2019 by the authors; licensee Cogitatio (Lisbon, Portugal). This article is licensed under a Creative Commons Attribution 4.0 International License (CC BY).

\section{Introduction}

When UN Secretary-General Ban Ki-moon spoke at a conference in Washington DC in April 2016 addressing the forced displacement of millions of people taking place at the time he said: "We are facing the biggest refugee and displacement crisis of our time. Above all, this is not just a crisis of numbers; it is also a crisis of solidarity....We must respond to a monumental crisis with monumental solidarity" (UN, 2016). It is easy to see why he believed that the refugee crisis was also a crisis of solidarity.
Unable to launch a common approach, what happened across Europe was a 'race to the bottom' in terms of developing deterrence policies to prevent refugees from entering a particular country. The refugee crisis caused a 'domino effect' when the migrant/refugee flows advanced from the southern and southeast part of Europe towards Central and Northern Europe (Agustín \& Jørgensen, 2019a). In the months following, most of the EU member states claimed that they were unable to cope with the situation and they found themselves in states of emergency, which called for-but also allowed for-exceptional measures, in reality breaching the 
principles of the Schengen agreement. Tensions arose around specific internal borders such as the FrenchItalian, the German-Austrian, the Slovenian-Austrian, the German-Danish, and the Danish-Swedish borders, and Europe went through a re-bordering (Agustín \& Jørgensen, 2019a).

While border closing illustrates a rejection of refugees, during the same period, Europe witnessed a wave of solidarity movements all across Europe taking different forms, depending on the context. The event at Budapest Keleti railway station is one example. On 4 September 2015, thousands of migrants and refugees had been encamped at the station. Hungarian police had started denying them access to the trains and were beginning to reroute them towards detention camps outside the city (De Genova, 2016). More than a thousand migrants and refugees then self-mobilized and started chanting 'Freedom!' and soon took to the road, heading towards Vienna in what was soon called the March of Hope (Agustín \& Jørgensen, 2019a). The Hungarian authorities capitulated and, with opportunistic motivations, assisted the marchers towards Austria and Germany who then declared their borders to be open. The 2015 long summer of migration marked a clash between the principles of Schengen-implying that asylum seekers could move to their preferred destinations after entering the EU-and those of Dublin II procedures (Bauböck, 2017). At the same time, the marchers called for European solidarity, symbolized by a man carrying the flag of the EU at the fore of the march, and it spurred the development of a multitude of solidarity networks-or made the already existing ones visibleacross Europe.

In the article, we argue that the European solidarity movement has shaped a new kind of cosmopolitanism: cosmopolitanism from below, which fosters an inclusionary universalism, which is both critical and conflictual. The urban scale thus becomes the place to locally articulate inclusive communities where solidarity bonds and coexistence prevail before national borders and cosmopolitan imaginaries about welcoming, human rights, and the universal political community are enhanced. Our focus to conceptualize the shaping of those imaginaries is mainly based on the cities. We do not wish to imply that cities are inclusive per se. We may find examples where cities or regional states take an exclusivist stance towards immigration and immigrants. However, we do see the new municipalism as a progressive political force. This implies looking not only at civil society movements, but also at the intersections between civil society and local or municipal governments. The implications are twofold: the articulation of cosmopolitanism from below in which civil society plays a major role in the redefinition of being European, in conflict with the EU institutions, and the network of municipalities as a genuine alternativewith all its limitations - to the nation states and nationalism as the dominant answer to the humanitarian crisis of 2015. To illustrate how this happens in practice, we use the example of Barcelona and its work on defining itself as a refugee city.

\section{Solidarities and Cosmopolitanism from Below}

Cosmopolitan imaginaries and practices "must entail forms of solidarity, which we understand as mutual constitutive relationships, the shaping of common ground, and the claim for an inclusive universality" (Agustín \& Jørgensen, 2019b, p. 133). It would be important here to explain our understanding of cosmopolitanism and solidarity. By referring to cosmopolitanism from below, we highlight the opposition to cosmopolitanism from above and place our approach within that of critical and conflictual cosmopolitanism (Agustín, 2017; Caraus, 2015). As pointed out by David Harvey (2009), critical cosmopolitanism must avoid false dichotomies between universal and rooted cosmopolitanism which ignore the dialectical relation between the universal and the particular and must aim to explain "moment of openness", which develops new relations between the self, the other, and the world (Delanty, 2006). Thus, cosmopolitanism does not imply an uncritical assumption of universalism or the rejection of the conflictual dimension. Universalism can indeed entail a dialectical function to contest existing imaginaries and open up the possibilities of thinking of alternative political orders or a more just world (Caraus, 2015). Cosmopolitanism from below combines rooted practices and solidarity relations without renouncing to a common ground shared by different solidarity movements. Such a common ground would be the basis for a new cosmopolitan 'we' (Agustín \& Jørgensen, 2019b; Caraus, 2017) grounded in inclusive universalism and the translation of rooted solidarity struggles. On the other hand, solidarity is a relational practice, and in opposition to reductionisms or strategic emptiness, solidarity is contentious; it emerges strongly in moments or conjunctures, it is generative of political subjectivities and collective identities, it entails alliance-building among diverse actors, it is inventive of new imaginaries, it is situated in space and time and organized in multi-scalar relations, and it is linked in different ways to institutions. Solidarity practices can, in any case, connect different places or geographies and enable relations that go beyond national borders, without having anything to do with nation-states' own interests (Featherstone, 2012).

The 'refugee crisis' and the arrival of refugees ruptures the imagined national community, as xenophobic reactions and implementation of restrictive policy measures make evident how national border-regimes create injustice, inequality, and divisions between human beings (Agustín \& Jørgensen, 2019b). The nation-state contains both inclusive and exclusionary forces. The exclusionary forces of citizenship are often felt by immigrants. The conjuncture of the 'refugee crisis' enhanced the exclusionary forces and led to a 'race to the bottom' between nation-states to limit the number of incoming refugees. Likewise, we can identify an ambiguity be- 
tween inclusion and exclusion within the EU framework. The European border regimes (Schengen and Frontex) at the same time have ideals of openness and free mobility as well as exclusionary aspects of controlling external borders. During the 'refugee crisis', the European Commission tried to appeal to the exclusionary forces by securing the external borders and by creating the EUTurkey deal, as well as launching a refugee relocation scheme in 2015 aiming at relocating 160,000 refugees who had arrived in Italy and Greece to other member states. The scheme was a failure on all accounts as it relocated less than 28,000 refugees and was terminated in September 2017. Thus, when we discuss practices of solidarity, we do so in relation to scales: local, regional, national, international, and transnational. The concept of scale connects to the (possible) institutionalization and materiality of solidarity (Agustín \& Jørgensen, 2019a).

The solidarity movements developing all over Europe show how such exclusivist regimes can be challengedand to some degree-undone and replaced by new imaginaries of inclusivist, just, and equal communities. This will not remove the nationalized identities supporting the existing regime(s), but it counters the existing hegemony both discursively and materially. David Featherstone has used the term "nationed geographies of crisis" to "suggest ways in which the nation is reasserted as the primary locus through which grievances are articulated and envisioned" (Featherstone, 2015, p. 21). As the term suggests these nationed geographies generate exclusionary articulations of the nation. Translocal solidarity networks connecting local and international geographies (Agustín, 2017), as well as cosmopolitan imaginaries, are essential to re-drawing progressive cartographies "and relate to diverse internationalist trajectories and connections" (Featherstone \& Karaliotas, 2018 , p. 299). In this regard, solidarities are central to the formation of transformative political subjectivities. Practices of solidarity can include people and communities excluded in existing policies, or they may enact new alternatives by generating entirely new subject identities (Bauder, 2016, p. 258).

Our conception of cosmopolitanism from below is grounded in the constitutive role of trans-local relations and their capacity to shape a cosmopolitan 'we', which is universal but rooted in practices and solidarity relations. It is important to highlight that talking about cosmopolitanism from below implies not renouncing the idea of universalism since the universal is the result of shaping inclusive common ground and not of the imposition of an abstract (exclusive) universalism. Thus, cosmopolitanism from below becomes the key to interconnecting the local practices of urban solidarity beyond national borders and, extremely important in our case, it reveals that the true agents of cosmopolitanism have always been migrants (Nail, 2015). In a similar manner to sanctuary cities, the solidarity city movement is, according to Thomas Nail, a migrant justice movement with the goal to create a true cosmopolis and bypass the idea behind nation-states. In order to achieve such a goal, new imaginaries must be generated which oppose the city (as a place for all residents) to the exclusionary national policies.

\section{Cities and Urban Solidarities}

Changing the focus and scale of the city brings a different perspective and practical alternatives which can challenge national governments and political inertia. Throughout the world, cities have responded to the disjuncture between exclusionary national migration and residency policies, and the need to be inclusive at the local scale (Bauder \& Gonzalez, 2018). Today, 55\% of the global population lives in cities; by 2050 that number will have increased to $68 \%$. Migrants and refugees may enter a given country in remote coastal areas or enter through the countryside or desert-but they inevitably move towards cities. As Benjamin Barber argued in If Mayors Ruled the World:

The politics of the city have a very different character to the ideological politics of the nation. [They] are about making things work-you've got to pick up the garbage, you've to keep the hospitals open, it doesn't matter if the immigrants are legal or illegalthey have children who get sick and who have to go to school, they ride buses, they drive cars. If you asked a mayor, 'Do you think immigrants should be allowed in or not?' they'd say, 'They are here'. (Barber, 2013)

Cities must find a way to secure access to legal residency, social protection, and cultural belonging, and accept the physical presence of illegal migrants. This is not an easy task, as national governments hold the right to issue visas, permits, residence, etc.-yet the new municipalist surge demonstrates that the municipality is becoming a strategically crucial site for the organization of transformative social change (Roth \& Russell, 2018). The city can be-and is-a strategic location for an emergent and active citizenship. As Jean McDonald has argued, the city is a space in which formal notions of citizenship have been challenged and where social, economic, and political rights typically associated with formal citizenship have been substantially demanded, acquired, and enacted by non-citizen actors (McDonald, 2012).

As we have already argued, we do not consider cities as such, as an inherently inclusionary or progressive force, as opposed to the nation-state. As studies on immigrant integration have shown, it is the particular urban context which shapes the approach to migration issues and the local politics of migration. De Graauw and Vermeulen (2016), for instance, show that cities are more likely to develop inclusionary approaches if the cities have left-leaning governments, if a large part of the electorate being immigrants, and by having an infrastructure of community-based organizations that actively represent immigrants' interest in local politics and policy- 
making. Alongside these tendencies, we could add that relations between (racialized) minorities and the political establishment, including the political left, also influence how urban solidarities are articulated. Bertie Russell (2019, p. 1) argues that: "Rather than essentializing cities as inherently progressive or democratic, the municipal is instead becoming framed as a 'strategic front' for developing a transformative politics of scale". From this, it follows that local loyalties and solidarities can be mobilized as part of a progressive scalar strategy without falling into the trap of a 'particular localism'. The latter notion stems from Mark Purcell, who claims that "as we discover, narrate, and invent new ideas about democracy and citizenship in cities, it is critical to avoid what I call the local trap, in which the local scale is assumed to be inherently more democratic than other scales" (Purcell, 2006, p. 1921). He further argues that scales "are socially constructed strategies to achieve particular ends. Therefore, any scale or scalar strategy can result in any outcome. Localization can lead to a more democratic city, or a less democratic one" (Purcell, 2006, pp. 1921-1922).

A lens to understand urban solidarities is the idea of 'sanctuary' cities. There are several definitions of sanctuary cities, which tend to differ according to national perspectives. A short functional definition is the deliberate municipal practice of not enforcing strict immigration laws. Instead of restricting access, the sanctuary city offers entitlements to otherwise illegalized migrants. Looking in particular at 'sanctuary' cities, Harald Bauder takes a spatial perspective and argues that such cities switch from the national to the urban scale by recognizing migrants through their domicile, their urban presence, rather than excluding them based on their national status (as 'illegal'). He contends that "the city, not the national, is the scale that defines community" (Bauder, 2017). We can identify this practice not only in sanctuary cities in North America, but also in the development of solidarity cities or Refuge Cities in Europe.

\section{Intersections between Civil Society Municipalities: Forging New Imaginaries}

In our own work, we have described solidarity cities through the notion of institutional solidarity, which represents the formalization in different degrees of solidarity, connecting the civil society arena with that of policymaking (Agustín \& Jørgensen, 2019a). Here we argue that the key to characterizing institutional solidarity (in opposition to institutionalized solidarity) is the capacity to enable (infra)structures to materialize solidarity and maintain (and foster) the connections with civil society and migrants and refugee organizations. For this reason, it is logical that institutional solidarity, as in the case of the 'sanctuary cities', happens at the local (urban) scale where the relations (and also the tensions) between institutions and civil society are closer. The relationship with the state (and its form of institutionalized solidarity) is often conflictual since the aims and realities dealt with are different. Where, for instance, the state can suggest an exclusivist approach limiting access to health, education, and labor, the municipalities at the local level have no choice but to deal with the people residing in the given municipality. At the local level, policy-based exclusivism is often replaced by local pragmatism or inclusiveness. This situation of conflict between the local and the national levels explains how the international scale is promoted to find transnational alternatives that go beyond the opposition and restrictions shown by nation-states. Regardless of the label, cities seeking to become spaces of sanctuary or solidarity must do so through institutionalization, alliance building, and civil society engagement.

We regard solidarity is contentious and, as such, a counter-hegemonic social and political mode of action which can unify diverse actors to come together to challenge authorities "in order to promote and enact alternative imaginaries" (Leitner, Sheppard, \& Sziarto, 2008, p. 157, who describe contentions politics). The potential and ability to not only envision but also enact alternative imaginaries is another important aspect of solidarity and one which is decisive for analyzing how solidarity responds to the 'refugee crisis' (Agustín \& Jørgensen, 2019a, chapter 2). The city has particularly been perceived as an open space of imagination: what Harvey (2000) has called "spaces of hope". Haiven and Khasnabish (2014) have coined the notion 'radical imagination', which they define as the ability to imagine the world, life, and social institutions not as they are but as they might otherwise be. They argue that "the radical imagination is not just about dreaming of different futures. It's about bringing those possibilities back from the future to work in the present, to inspire action and new forms of solidarity today". (Haiven \& Khasnabish, 2014, p. 3)

\section{Barcelona's Municipalism and Refuge Plan}

In May 2015, Barcelona en Común (Barcelona in Common), a citizen platform created less than one year before the elections, won the municipal elections. Ada Colau, a well-known social activist who is particularly involved in the stop-evictions movement, became mayor. One year later, Barcelona en Común launched the guide "How to Win Back the City in Común", elaborated by their own International Committee. The intention of the guide is already presented in the first lines:

From the very beginning, those of us who participate in Barcelona En Común were sure that the democratic rebellion in Barcelona wouldn't be just a local phenomenon. We want Barcelona to be the trigger for a citizen's revolution in Catalonia, Spain, Southern Europe, and beyond. (Barcelona en Común, 2016)

Two dimensions converge here: the local and the international. The experience of Barcelona, being locally rooted, aspires to connect with other international experiences. 
The place of politics (with citizens as its actors) is the city and the connection between cities creates a new scale that is not monopolized by the nation states and is open to new forms of cooperation between institutions and civil society. Thus, Barcelona becomes "the heart of a new global political phenomenon known as municipalism" (Gessen, 2018), which challenges the distinction between traditional political parties and citizens, and between institutions (and political decision-making) and civil society. Municipalism reflects the major role played by the cities and attempts to "open up important fields of action when it comes to the flow of global capital into and out of cities; the ecological consequences of overpopulation; and the growing social, economic, and ideological divide between urban, suburban, and rural areas" (Rubio-Pueyo, 2017). Migration and refuge have also become part of those important fields, as proven after the 'refugee crisis' in 2015.

Following these statements, we consider municipalism as a space for radical imagination since the possibilities of producing policies driven by politicians in cooperation with citizens (as a 'democratic rebellion') are already provoking new ways of solidarity that can inspire other spaces (cities) and even change the way we understand politics. Regarding migration, the radical imaginary on democracy forged by municipalism is shaped by cosmopolitanism from below, where the local connects with the universal and the city become the space of coexistence between equals. Within this logic, the City Council launched Barcelona's Refugee City Plan in 2015, conceived as "a citizen space to channel urban solidarity and to set up coordinated ways of participating in its application" (Barcelona Ciutat Refugi, n.d.). The plan is a reaction against the restrictive politics towards refugees carried out by the Spanish government. Despite the commitment to receive 17,313 refugees, according to the refugee relocation scheme and the resettlement scheme, Spain received only 1,910 (Sánchez \& Sánchez, 2017). Barcelona's response connected with the multiple forms of solidarity expressed by civil society. The idea of 'refugee city' already activates an imaginary of the city as a place of solidarity in contrast with the hostility shown by the national government. The imaginary of solidarity converges with that of municipalism. This confluence explains why the idea of 'refuge cities' evolved quickly into the establishment of a national network in Spain and a European Network. Although the state is the main decision-maker in asylum policies, municipalism entails a new space to do everyday politics and to challenge the absolute lack of a humanitarian approach by the national government.

Previous to the launch of the Refuge City initiative, Mayor Ada Colau wrote a letter to Mariano Rajoy which reflected two totally different modes of approaching the solidarity movement and the efforts made by civil society. Colau offered to cooperate and receive more refugees and emphasized the role that the representative institutions should play: "We as institutions must rise to the occasion of this wave of solidarity. It is not about charity. It is an obligation" (Colau, 2015). Not surprisingly, the Spanish President, Mariano Rajoy, not only refused the offer but also the possibility of managing the situation at a level which was not the European one. He did not consider that the city level should be the level of action, and not even the nation-state. Consequently, Rajoy talked about solution patches, or short-term measures, and thus removed the political solutions from the actions carried out by the citizens. On the other hand, the idea sustained by Colau of institutions obliged to follow the solidarity movement points to a completely different direction in which the solutions are designed from below and transcend the interests of the national governments and the constraints imposed by the EU. Both positions illustrate the differentiation above between institutional and institutionalized solidarity. Furthermore, the case of Barcelona offers a dual horizontal platform to articulate cosmopolitanism from below: between institutions and civil society (by strengthening the link and cooperation) and between cities from different geographies (by establishing a national and international network of 'refuge cities').

Barcelona as a 'refuge city' develops the idea of municipalism reflected in its "inter-city network's four strategies-the reception model, care for refugees already in Barcelona, citizen participation and information, and action abroad" and "emphasizes the assertive influence of the local government" (Irgil, 2016, p. 10). It does not imply a completely harmonious relation between civil society and the municipality or the fulfillment of all goals, which is far from happening. However, as Hansen (2019) has pointed out, the 'refuge city' "must crucially be read as a Europe-wide campaign against a climate of fear and closure". Therefore, urban solidarities and cooperation between civil society and institutions become relevant to promote an imaginary which works against the one produced from nationalist and xenophobic positions.

Finally, it is important to stress that the tensions between civil society and the municipality have become evident in the case of the migrants and the enormous difficulties in offering satisfactory solutions from local institutions. The case of the manteros (street vendors) is probably the most emblematic. The recognition of unions of manteros, as well as the willingness of the City Council to improve the conditions of the group, have been obscured by the continuing police control and repression. The critiques of manteros were also aimed at the municipal initiative to create cooperatives by ex-vendors who want to sell 'legal' products. The initiative has been considered as an attempt to improve the image of the city council without addressing the real problems on the street. The case of the manteros would be an example of the limitations of the left in Spain (Barcelona en Común, but also Podemos) to change institutions substantially (Sabaté, 2019). The difficulties in opening up institutions to groups like manteros are also reflected in the way in 
which solidarities are constructed, particularly from an institutional perspective.

\section{Institutionalizing and Imagining Solidarities}

The urban scale (and the corresponding form of institutional solidarity) opens up the potential to articulate solidarity but still in relation to other scales and their constraints, both nationally and internationally. The focus on local realities also implied that the Barcelona as Refuge City Plan had to modify their goals and understanding of solidarity. The initially declared goals consisted of providing "support for refugees reaching Barcelona under their own steam, not part of European quotas and initiatives for direct support for the Mediterranean cities most affected by the humanitarian crisis" (Barcelona Ciutat Refugi, 2016). Nonetheless, the strategy changed to address the everyday situations not corresponding with the wave of solidarity from 2015. The new strategy consisted of: the strengthening of the Care Service for $1 \mathrm{mmi}$ grants, Emigrants and Refugees (SAIER); the application of the program for accommodation and support called "Nausica"; increasing work on awareness and education; the creation of the neighborhood document brochure in order to facilitate the integration of residents regardless of their legal condition; and continuing with international cooperation. All these efforts reflect a new phase of institutional solidarity. In a conversation with Ignasi Calbó, coordinator of the plan, he explained that there was a shift from the 'refugees welcome' phase to managing other realities and situations which did not correspond with the most stereotypical media representations of refugees. In our understanding, this second phase implies a new imaginary of refugees if we consider 'refugees welcome' as the first moment of solidarity. The imaginary provoked by the Syrian 'refugee crisis' was very powerful and motivated many of the acts of solidarity. By recognizing other realities to deal with, the City Council likewise demanded a change of imaginary related to the autonomy of immigrants and the city as a place of coexistence.

Gloria Rendón, coordinator of SAIER and the "Nausica" program, explains the change with the following words: "When the 'Barcelona Refuge City Plan' was created, the impact on the city was more media than real.....Now we have a real impact but less media" (Barcelona Ciutat Refugi, 2017a). Her words portray quite accurately how the Refuge City was indeed part of the wave of solidarity since it emerged from civil society's demands, and how it needs to adapt to the existing scenario in the aftermath of the crisis. Therefore, we identify tension between institutionalizing and imagining solidarity since the imaginary of refugees differs from the one used by the municipality. This situation requires the responsible people of the plan to contest the idea that no refugees were arriving in Barcelona by highlighting that refugees were coming, but with a different profile than expected in 2015 and that the new refugees and asylum seekers do not reach the same media scope. The interest in addressing realities could evolve into disconnection between the political institutions and the citizens and put the intersection between politicians (and policy makers) and citizens at risk. Therefore, the second phase of institutional solidarity focuses on increasing solidarity through participation. Pablo Peralta de Andrés, responsible for sensitivity and participation of the plan, places urban solidarity at the level of the neighborhood:

When we talk about solidarity and refugees, there is a problem in that we talk in general terms. If we only look at their administrative situation and their needs, we ignore their particularities: It is not the same to be a man coming from Venezuela, a woman coming from Pakistan, or a child from Honduras. So solidarity shouldn't be with the refugees in general but with a population that is coming and with a logic of a good and new neighborhood. (Barcelona Ciutat Refugi, 2017b)

Although the plan aims to enhance participation in the neighborhoods by supporting the ongoing work of social organizations, it is difficult not to interpret the words of Peralta de Andrés in terms of cosmopolitanism from below. He rejects talking about solidarity in general and prefers contextualized solidarity instead. The opposition to reducing refugees to an abstraction and solidarity to a general relation shows how cosmopolitanism from below can contribute to a universal rooted in local realities. As a consequence, there is a shift from talking about people as 'refugees' in general to talking about 'communities and neighborhoods', enhancing solidarity links among them.

The third phase of Barcelona as a 'refuge city' is provoked in this case by civil society. In February 2017, around 160,000 people demonstrated in the streets of Barcelona to demand a change in refugee policies. The campaign "Casa Nostra, Casa Vostra" ("Our Home, Your Home") recovered the spirit of the 'refugees welcome' wave and the constitution of a cosmopolitan 'we' as expressed in banners such as: 'We Welcome', 'No One Is Above Another, No One Is Illegal!' or 'Enough Excuses!'. The solidary 'us' contrasts with the reticent 'them', attributed to politicians incapable of taking the necessary actions to receive refugees. However, local and regional politicians participated in the demonstration since it was mainly the Spanish government that was blamed. One of the organizers of the campaign, Rubén Wagensberg (cited in Colás, 2017), explained that the initiative emerged from a group of Catalan people who met in the refugee camps in the North of Greece, on the border with Macedonia. When the refugees were being evicted, spontaneous camps were created and managed by volunteers. Some of those volunteers decided to expand their experience and connect the geographies of resistance from Greece to Barcelona. The forging of the campaign shows how trans-local solidarity works by con- 
necting people and geographies. The mobilization also showed the willingness of civil society to influence, from the city level, national and international politics to receive more refugees. Civil society scales both the problem and the solutions by targeting the national government and proving the influence of trans-local solidarities.

Although the City Council lacked continuity in civil society actions and civil society lacked more political action, the mobilizations of 2017 reinvigorated the imaginary of refuge as an international issue and reclaimed playing an active role. Solidarities are thus local and trans-local and the tensions, or different perspectives, between the municipality and civil society are produced by different ways of institutionalizing and imagining solidarity.

\section{Scaling-Up Solidarity}

Urban solidarity emerges as the necessity of exploring an alternative to the states, with its obstruction of the reception of refugees, and the $\mathrm{EU}$, incapable of offering coordinated and satisfactory solutions. Besides strengthening local solidarities, Barcelona has developed a determination to scale up solidarity and connect different cities. In this way, the municipal level becomes an alternative level of governance which is shaped by other channels than the national and the EU ones. Three initiatives are important to remark: the Refuge Cities network, both Spanish and European, the EU initiative "Solidarity Cities", and the internationalization of municipalism through "Fearless Cities". The latter is not specifically about migration and refugees, but migration was highlighted as one of the core issues of the new municipalism. Together, the three initiatives address different types of institutional solidarity across borders, with the involvement of the city council and civil society.

In September 2015, Ada Colau, together with Anne Hidalgo, Mayor of Paris, Spyros Galinos, Mayor of Lesbos, and Giusi Nicolini, Mayor of Lampedusa, wrote an open letter entitled We, the Cities of Europe. They opposed the will of citizens to the lack of will of the states. The gap between the cities and the states generates a new space of governance: "We, the cities of Europe, are ready to become places of refuge. We want to welcome these refugees. States grant asylum status but cities provide shelter" (Colau, Hidalgo, Galinos, \& Nicolini, 2015) The idea of creating a Refuge Cities network was launched also in Spain and represented the cooperation between the two most significant cities of municipalism: Barcelona and Madrid, and 25 other cities which joined the network.

Fearless Cities is an example of both the scaling-up of the organizing processes as well as the expanding of their focus. In June, Barcelona en Común hosted the first international Fearless Cities summit. The summit brought together more than 700 officially registered participants from six continents. Fearless Cities gatherings have been organized throughout 2018 (in Warsaw, New York, Brussels, and Valparaiso). Fearless Cities was the first time many of these initiatives were brought into conversation (Russell, 2019). The gathering in Barcelona, as well as the work that occurred before June 2017, point to an orientation towards urban politics and shared commitment to the progressive social force that Barcelona en Común had come to represent (Russell, 2019). The Fearless City summit, as the name indicates, not only related to the issue of refugees and migration, but to how cities have a transformative potential based on local solidarities and with the ability to both develop new imaginaries and materialize these through practices. The summit addressed issues such as commoning practices, new participatory models of budgeting, developing new models of direct democracy, etc. The organizers describe the purpose and work ahead as: "[A] goal of radicalizing democracy, feminizing politics, and standing up to the far right. Since then, these neighborhood movements, mayors, and local councilors have been collaborating to build global networks of solidarity and hope from the bottom up" (Fearless Cities, 2018).

Although migration and refugee issues were central to the summit-the summit was initiated by a public rally for the establishment of a global networks of refuge and hope with mayors from 16 cities and three continents standing as organizers-it can still be discussed if a platform such as Fearless Cities is favorable for transforming urban solidarities into practices relating to migrants and refugees. As pointed out by Gonick (2017), neither "Fearless Cities" nor Barcelona municipalism have been capable of incorporating the question of immigration and ethnic and racial difference as constitutive of urban governance since migrants still appear as objects of political action rather than subjects. Ignasi Calvó (quoted in Ciudades sin Miedo, 2018, p. 182) argues that "migration and refugee policies must influence all the other policies in the municipal sphere, from those of economic and social character to urban planning. They should be perceived as a value, not as a problem". While this is doable at the local level, it remains to be seen how the upscaling can forge trans-local solidarities and how it can affect the development of progressive politics and policies. Fearless Cities is a direct response to what Wodak (2015) has described as a "politics of fear", which is a normalization of nationalistic, xenophobic, racist, and antiSemitic rhetoric. Gatherings such as the Fearless Cities summits are examples of how trans-local solidarities and cosmopolitanism from below challenge established and institutionalized politics of fear.

\section{Concluding Remarks}

In this article, we have focused on the intersections between civil society and local or municipal governments and discussed how urban solidarities can materialize into new practices based on cosmopolitanism from below. In this political geography, cities hold a special role. Returning to Barber's (2013) question, "what would happen if Mayors ruled the world?", we will let lago Martínez 
from the platform La Marea Atlantica, which governs La Coruña's council, indirectly answer the question:

If the 19th century was that of Empire, and the 20th that of the nation-state, the 21st is the century of the city....Cities are our greatest hope for democracy. While traditional political institutions lose space and power in a system which has surpassed the boundaries of the nation-state, new local sovereignties emerge as authentic protagonists of the present through their capacity to respond...to the key challenges of our age. (Gilmartin, 2018)

In our example of Barcelona as a 'refuge city', we see how a Spanish city engages in a progressivist manner to develop mechanisms of inclusion towards migrants and refugees. In this way, the new municipalism in Barcelona (and the democratic and inclusive imaginaries associated with it) becomes a paradigmatic example of how a solidarity city develops and what kind of potential it holds. Not all cities are like Barcelona, and as we previously argued in this article that we should be aware not to assume that all cities are progressive per definition. From the perspective of academia, these are analytical questions and we not only need empirical studies of the many different city approaches but also to theorize the dynamics of solidarity cities.

\section{Acknowledgments}

We are grateful for the comments and suggestions from the three external reviewers.

\section{Conflict of Interests}

The authors declare no conflict of interests.

\section{References}

Agustín, Ó. G. (2017). Dialogic cosmopolitanism and the new wave of movements: From local rupture to global openness. Globalizations, 14(5), 700-713.

Agustín, Ó. G., \& Jørgensen, M. B. (2019a). Solidarity and the 'refugee crisis' in Europe. Cham: Palgrave McMillan.

Agustín, Ó. G., \& Jørgensen, M. B. (2019b). Transnational solidarity and cosmopolitanism from below: Migrant protests, universalism, and the political community. In T. Caraus \& E. Paris (Eds.), Migration, protest movements and the politics of resistance (pp. 133-151). London: Routledge.

Barber, B. R. (2013). If mayors ruled the world: Dysfunctional nations, rising cities. New Haven, CT: Yale University Press.

Barcelona Ciutat Refugi. (n.d.). Espacio ciudadano [Citizens' space]. Ciutat Refugi. Retrieved from http:// ciutatrefugi.barcelona/es/espacio-ciudadano

Barcelona Ciutat Refugi. (2016). 'Barcelona, refuge city', a year on. Ciutat Refugi. Retrieved from http://ciutatrefugi.barcelona/en/noticia/barcelonarefuge-city-a-year-on_434720

Barcelona Ciutat Refugi (2017a). En Barcelona atendemos a once perfiles de refugiados diferentes [In Barcelona we receive 11 different types of refugee profiles]. Ciutat Refugi. Retrieved from https://ajuntament.barcelona.cat/turisme/es/ noticia/en-barcelona-atendemos-once-perfiles-derefugiados-diferentes_537361

Barcelona Ciutat Refugi. (2017b). Muchas cosas pequeñas al final forman un gran qué [In the end, many small things shape a big question mark]. Ciutat Refugi. Retrieved from http://ciutatrefugi.barcelona/ es/noticia/muchas-cosas-pequenas-al-final-hacenun-grande-que_527424

Barcelona en Común (2016). How to win back the city en común: Guide to building a citizen municipal platform. Barcelona en Común. Retrieved from https://barcelonaencomu.cat/sites/default/files/ win-the-city-guide.pdf

Bauböck, R. (2017). Europe's commitments and failures in the refugee crisis. European Political Science, 17(1), $1-11$.

Bauder, H. (2016). Understanding Europe's refugee crisis: A dialectical approach. Geopolitics, History and International Relations, 8(2), 64-74.

Bauder, H. (2017). Sanctuary cities: Policies and practices in international perspective. International Migration, 55(2), 174-187.

Bauder, H., \& Gonzalez, D. A. (2018). Municipal responses to 'illegality': Urban sanctuary across national contexts. Social Inclusion, 6(1), 124-134.

Caraus, T. (2015). Cosmopolitanism of dissent. In T. Caraus \& C. Pârvu (Eds.), Cosmopolitanism and the legacies of dissent (pp. 1-18). London: Routledge.

Caraus, T. (2017). Cosmopolitanism beyond mottos: Cosmopolitan Representation in the Global Protests. Globalizations, 14(5), 730-745.

Ciudades Sin Miedo. (2018). Guía del movimiento municipalista global [Guide of the municipalist movement]. Barcelona: Icaria.

Colás, J. (2017, January 5). Rubén Wagensberg: Me da vergüenza ser europeo [Rubén Wagensberg: I'm ashamed of being European]. Revista R@mbla. Retrieved from https://www.revistarambla.com/rubenwagensberg-ma-da-verguenza-ser-europeo

Colau, A. (2015). Carta a Rajoy. Ajuntament de Barcelona. Retrieved from http://ajuntament.barcelona.cat/ alcaldessa/ca/blog/carta-rajoy

Colau, A., Hidalgo, A., Galinos, S., \& Nicolini, G. (2015). We, cities of Europe. Ada Colau Blog. Retrieved from http://adacolau.cat/en/post/we-cities-europe

De Genova, N. (2016). The 'crisis' of the European border regime: Towards a Marxist theory of borders. International Socialism, 150, 31-54.

De Graauw, E., \& Vermeulen, F. (2016). Cities and the politics of immigrant integration: A comparison of Berlin, 
Amsterdam, New York City, and San Francisco. Journal of Ethnic and Migration Studies, 42(6), 989-1012.

Delanty, G. (2006). The cosmopolitan imagination: Critical cosmopolitanism and social theory. The British Journal of Sociology, 57(1), 25-47.

Fearless Cities. (2018). Fearless cities: The global municipalist movement. Fearless Cities. Retrieved from http://fearlesscities.com/en/about-fearless-cities

Featherstone, D. (2012). Solidarity: Hidden histories and geographies of internationalism. London: Zed Books Ltd.

Featherstone, D. (2015). Thinking the crisis politically: Lineages of resistance to neo-liberalism and the politics of the present conjuncture. Space and Polity, 19(1), 12-30.

Featherstone, D., \& Karaliotas, L. (2018). Challenging the spatial politics of the European crisis: Nationed narratives and trans-local solidarities in the post-crisis conjuncture. Cultural Studies, 32(2), 286-307.

Gessen, M. (2018, August 6). Barcelona's experiment in radical democracy. The New Yorker. Retrieved from https://www.newyorker.com/news/ourcolumnists/barcelonas-experiment-in-radicaldemocracy

Gilmartin, E. (2018, September 10). The mayors and the movements. Jacobin. Retrieved from https://www.jacobinmag.com/2018/10/fearlesscities-review-ada-colau

Gonick, S. (2017). Fearless cities: A dispatch from Barcelona. Urban Democracy Lab. Retrieved from https://urbandemos.nyu.edu/2017/06/15/fearlesscities-a-dispatch-from-barcelona

Haiven, M., \& Khasnabish, A. (2014). The radical imagination: Social movement research in the age of austerity. Nova Scotia: Fernwood Publishing.

Hansen, B. R. (2019). Barcelona: City of refuge and migration. Unpublished manuscript. Retrieved from https://www.academia.edu/38377339/Barcelona_City_of_Refuge_and_Migration

Harvey, D. (2000). Spaces of hope (Vol. 7). Berkeley, CA: University of California Press.

Harvey, D. (2009). Cosmopolitanism and the geographies of freedom. New York, NY: Columbia University Press.

Irgil, E. (2016). Multi-level governance as an alternative: The municipality of Barcelona and the Ciutat Refugi Plan. Glocalism: Journal of Culture, Politics and Inno- vation, 3, 1-21.

Leitner, H., Sheppard, E., \& Sziarto, K. M. (2008). The spatialities of contentious politics. Transactions of the Institute of British Geographers, 33(2), 157-172.

McDonald, J. (2012). Building a sanctuary city: Municipal migrant rights in the city of Toronto. In P. Nyers \& K. Rygiel (Eds.), Citizenship, migrant activism and the politics of movement (pp. 141-157). London: Routledge.

Nail, T. (2015). Migrant cosmopolitanism. Public Affairs Quarterly, 29(2), 187-199.

Purcell, M. (2006). Urban democracy and the local trap. Urban Studies, 43(11), 1921-1941.

Roth, L., \& Russell, B. (2018). Translocal solidarity and the new municipalism. Roar, Autumn(8), 80-93.

Rubio-Pueyo, V. (2017). Municipalism in Spain. From Barcelona to Madrid, and beyond. New York, NY: Rosa Luxemburg Stiftung. Retrieved from http:// www.rosalux-nyc.org/wp-content/files_mf/ rubiopueyo_eng.pdf

Russell, B. (2019). Beyond the local trap: New municipalism and the rise of the fearless cities. Antipode. https://doi.org/10.1111/anti.12520

Sabaté, A. (2019, February 21). Colau cierra el círculo represivo contra los manteros con el que inició su mandato [Colau closes the repressive circle against the street sellers with which she started her term]. Izquierda Diario. Retrieved from https://www. izquierdadiario.es/Colau-cierra-el-circulo-represivocontra-los-manteros-con-el-que-inicio-su-mandato

Sánchez, G., \& Sánchez, R. (2017, September 25). España entre los Estados que más han incumplido su cuota de refugiados junto a los países del Este [Spain, together with the Eastern European countries, among the countries which most severely fail to comply with their quota]. eldiario.es. Retrieved from https:// www.eldiario.es/desalambre/Espana-incumplidocuota-refugiados-paises_0_690481792.html

UN. (2016). Refugee crisis about solidarity, not just numbers, secretary-general says at event on global displacement challenge. United Nations. Retrieved from https://www.un.org/press/en/2016/ sgsm17670.doc.htm

Wodak, R. (2015). The politics of fear. Oxford: Sage Publications.

\section{About the Authors}

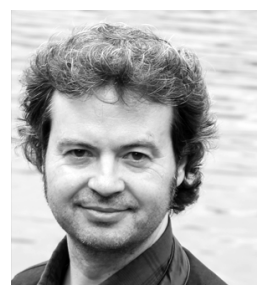

Óscar García Agustín is Associate Professor in the Department for Culture and Global Studies at Aalborg University, Denmark. He is head of the DEMOS research group. He works on populism, social movements, and migration. He recently co-edited Podemos and the New Political Cycle. Left-Wing Populism and Anti-Establishment Politics (Palgrave, 2018) and, with Martin Bak Jørgensen, the books Solidarity Without Borders. Gramscian Perspectives on Migration and Civil Society (Pluto Press, 2016) and Solidarity and the 'Refugee Crisis' in Europe (Palgrave, 2019). 


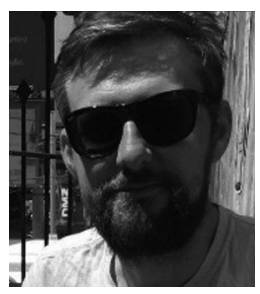

Martin Bak Jørgensen is Associate Professor in the Department for Culture and Global Studies at Aalborg University, Denmark. His main research areas include migration and integration policies, social movements, civil society, and precarity. He has co-edited with Carl-Ulrik Schierup Politics of Precarity: Migrant Conditions, Struggles and Experiences (Brill, 2017), and with Oscar Garcia Agustın the books Solidarity without Borders. Gramscian Perspectives on Migration and Civil Society (Pluto Press, 2016) and Solidarity and the 'Refugee Crisis' in Europe (Palgrave, 2019). 